\title{
Sekulariseringens betydning
}

\author{
- og religionens beskaffenhed i Danmark i dag1
}

HANS RAUN IVERSEN

ENGLISH ABSTRACT: Taking stocks of research and debate on religion and secularization this contribution promotes Charles Taylor's understanding of life in secular society as a historically developed situation where people in the West live under cross pressure from competing horizons of meaning and beliefs. Therefore for most people existential orientation has become ambivalent and fluctuating. This again implies that the question of religion is not a simple matter of choosing between different options but an ongoing struggle for existential orientation in an ever changing social, communicative and emotional context. In daily life the Danes, independent of their individual faith, live quietly as if there is no God. At other times, e.g. when struck by life threatening illness, the same people are struggling to find a way in their ambivalent and fluctuating existential orientation. This new character of religion today calls for reconsideration of the methods in the study of religion today.

DANSK RESUMÉ: I et forsøg på at gøre status over forskningen og debatten om religion og sekularisering fremhæver dette bidrag Charles Taylors forståelse af livet $i$ et sekulariseret samfund som en historisk bestemt situation, hvor mennesker $i$ vesten lever under et konstant krydspres mellem forskellige betydningshorisonter med det resultat, at deres eksistentielle orientering er ambivalent og fluktuerende. Spørgsmålet om religion handler således ikke om et simpelt valg mellem forskellige standpunkter, men om en stadig kamp for eksistentiel orientering stærkt afhængigt af de skiftende sociale, kommunikative og følelsesmæssige sammenhænge, man indgår i. Til daglig lever de fleste danskere, uanset deres individuelle tro, stille og roligt, som om Gud ikke er til. Til andre tider, fx når de stilles over for en dødelig sygdom, kæmper de samme mennesker med at finde vej $i$ deres ambivalente og fluktuerende, eksistentielle orientering. Religionens nye beskaffenhed kalder på genovervejelse af metoderne i studiet af religion $i$ dag.

1 Oplæg ved religionsvidenskabelig workshop på Aarhus Universitet 1. december 2010. 
KEYWORDs: Theory of secularization, a secular age, cross pressure, existential ambivalence, dimensions of religion, approaches to the study of religion today.

Denne artikel søger at kaste lys over sekulariseringens betydning og religionens beskaffenhed i dag i et protestantisk, nordvestligt land som Danmark. Emnerne kan næppe afklares endeligt ad empirisk vej, men det er vigtigt at orientere sig om dem, bl.a. med henblik på fornyede empiriske undersøgelser. Min antagelse er, at vi kan skyde os ind på en orientering ad ræsonnementets og argumentationens vej - gennem bestemte iagttagelser og især ved at trække på Charles Taylors historisk udviklede sekulariseringsteori, som den er fremlagt i hans storværk A Secular Age fra 2007. Det er artiklens tese, at svarene på de to spørgsmål om sekulariseringens betydning og religionens beskaffenhed hænger tæt sammen, fordi sekulariseringsprocessen er indlejret i nogle kulturelle udviklingslinier, der ændrer de eksistentielle livsvilkår og dermed transformerer religionens betingelser i vort samfund.

Artiklens første del fremhæver, at sekulariseringsprocessen har efterladt vestlige, især nordvesteuropæiske samfund i en ny situation, hvor sekularitet som fravær af religion i bestemte sfærer og måske hos visse mennesker er en klar og væsentlig historisk ny realitet, ligesom også sekularisme som en politisk holdning, der ønsker at fremme sekularitetet, er det. Jürgen Habermas karakteriserer vores samfund som 'postsekulært', altså på engang grundlæggende sekulært og præget af religiøse grupperinger og positioner. Her er der en vis indsigt at hente, især i politisk henseende; men for at forstå de eksistentielle vilkår hos det store flertal af enkeltindivider og dermed religionens betydning for dem, må vi vende os mod Charles Taylors lange perspektiv på sekulariseringsprocessen og hans forståelse af sekularisering som nye vilkår for eksistentiel meningsdannelse.

Artiklens anden del søger hernæst at skyde sig ind på, hvor og hvad religion er i den brede befolknings liv i dag. Her er der brug for nuancerede overvejelser, for tolkningsmulighederne går i vidt forskellige retninger - fra et syn, hvor Danmark ses som et 'samfund uden Gud' til tale om 'religionens tilbagekomst'. I et forsøg på afklaring diskuterer artiklen først det gamle spørgsmål om religionens dimensioner: Hvad er det for fænomener, vi er på udkig efter, eller bør være på udkig efter, når vi studerer religion? I anden omgang trækker artiklen på det store materiale fra interviewundersøgelser gennemført i regi af forskningsnetværket 'Tro og helbred' blandt danske patientgrupper i de senere år (se http:/ / tro-helbred.org/). Her lader empirien sig i slående grad tolke ud fra Taylors sekulariseringsforståelse: Mange samfundsmæssige ændringer af betydning for religionen er indtruffet gennem de protestantiske samfunds snart 500-årige historie (fx sfæreopdeling, produktionsmådeskift og markedsgørelse, jf. Bäckström et al. 2005); men det afgørende er det krydspres under konkurrerende betydningshorisonter og dermed den ambivalens, som den enkeltes eksistentielle meningsdannelse er underlagt som et vilkår i dag. Set fra subjektets side kan sekularisering således oversættes til 'ambivalens i den eksistentielle meningsdannelse'. 


\section{Sekulariseringens betydning}

Som mange andre knytter Jürgen Habermas sin forståelse af sekulariseringsprocessen sammen med modernitetens gennemslag. I sine yngre dage understregede han, at tilbageværende - usamtidige - religiøse grupper godt kunne deltage i demokratiet, de skulle blot sprogliggøre det sakrale ved at oversætte deres religiøst betingede ideer til sekulære diskurser, som per se måtte have monopol i den demokratiske diskussion (jf. Habermas 1982). I de senere år har Habermas modificeret sit standpunkt $i$ to skridt: Først har han fremhævet, at de sekulære også har pligt til at søge at forstå de religiøse - der skal altså være gensidighed i arbejdet med gensidig forståelse. I anden omgang har han fremhævet, at de vestlige samfund ikke kan overleve uden et bevidst træk på samfundenes kristne grundlag, som det derfor er en demokratisk pligt at sætte sig dybt ind i, alt andet er blot 'postmoderne snak' (Habermas 2006, 151). I et bidrag fra 2008, der kendetegnende hedder "Notes on a post-secular society", har Habermas forsøgt at sammenfatte sit syn, der er ganske klart i samfundspolitisk henseende: Moderniteten og sekulariseringen kan ikke længere ses som på en gang sammenhængende og uafvendelige processer; så meget des mere må samfundet indrettes og borgerne indgå i gensidige forståelsesbestræbelser mellem sekulære og religiøse grupper:

A complementary learning process is certainly necessary on the secular side unless we confuse the neutrality of a secular state in view of competing religious world views with the purging of the political public sphere of all religious contributions... Two reasons speak in favor of such liberal practice. First, the persons who are neither willing nor able to divide their moral convictions and their vocabulary into profane and religious strands must be permitted to take part in political will formation even if they use religious language. Second, the democratic state must not pre-emptively reduce the polyphonic complexity of the diverse public voices, because it cannot know whether it is not otherwise cutting society off from scarce resources for the generation of meanings and the shaping of identities (Habermas 2008).

Selv om man er enig i Habermas' samfundsfilosofiske og politiske overvejelser, ${ }^{2}$ må man spørge, om man det er tilstrækkeligt, som Habermas og mange andre fortsat gør det, at forstå sekulariseringen som, hvad Charles Taylor kalder en 'subtraktionsproces', hvor noget, der var engang, forsvinder mere og mere, selv om det dog lever videre i bestemte grupperinger, som vi må se at få inkluderet i samfundet alligevel.

Taylor tager udgangspunkt i tre forskellige forståelser af sekularisering, hvoraf de to første flittigt anlægges af religionssociologer: ${ }^{3}$ 1) Sekularisering som frigørelsen af

2 Det er der gode grunde for at være. I The Hedgehog Review Fall 2010 har en række samfundstænkere, inkl. Charles Taylor, argumenteret for, at et (religiøst) pluralistisk samfund må bygge på sekularisme i regeringsførelsen. For Taylor er det afgørende, at sekularisme ikke handler om at bekæmpe religion, men om at fremme frihed, lighed og broderskab (Taylor 2010).

3 Jf. de udførlige oversigter over og debatter mellem positionerne i After Secularization. The Hedgehog Review 
staten og dens institutioner fra religionen, 2) sekularisering som svind i religiøs tro og praksis i befolkningen og endelig 3) sekularisering som forandrede vilkår for livstolkningen, som er blevet et ambivalent, dvs. et reflekteret og problematiseret valg, hvor man ofte lige så godt kan hælde til det ene som det andet. Taylors nægter ikke, at der - i et politisk eller sociologisk perspektiv - er masser af empirisk belæg for at tale om sekulariseringen i de to første betydninger. Men han finder det utilstrækkeligt, idet hans interesse er at beskrive sekulariseringens betydning for den enkeltes livsforståelse. Han gør begrebet 'fullness' til udgangspunkt for sin analyse: "Somewhere, in some activity, or condition, lies a fullness, a richness; that is, in that place (activity or condition), life is fuller, richer, deeper, more worth while, more admirable, more what it should be" (Taylor 2007, 5). Som god katolik forestiller Taylor sig øjensynligt, at oplevelsen af livsfylde, 'fullness', primært men ikke eksklusivt har ligget og bør kunne ligge i kirken. Til oplevelsen af 'fullness' knyttes både en afhængighedsfølelse, en umiddelbar følelse af sikkerhed og en form for transcendenserfaring - ofte i forbindelse med rituel praksis og oplevelse af det hellige i kirken, naturen, samfundet og/eller livets vilkår.

Den i øvrigt ikke særligt udarbejdede brug af 'fullness' er én af de diskutable ideer i Taylors store bog. De fleste kommentatorer har imidlertid sluttet op om indsigterne i hans store arbejde med at afdække de mange og lange filosofiske, idehistoriske og mentalitetsmæssige udviklingstræk bag den nuværende situation, hvor sekulariseringen i form af livstolkningsmæssig krydspres og ambivalens møder os som et fait accompli, der stiller bestemte fælles eksistentielle vilkår for folk flest i de nordvestlige lande. Jeg har andetsteds (Iversen 2010) beskrevet de seks hovedfaser/elementer, der ifølge Taylors analyse er særligt vigtige i de sidste 500 års sekulariseringsproces. Sagt i stikordsform handler det om: 1) Reformationen, der demokratiserer adgangen til det helliges kilder, inkl. Gud, mens kirken står til stadig reformation, akkurat som samfundet senere gør det i efterfølgende revolutioner. 2) Civilisationsprojektet, der fremholder den ide, at der kan nås en fælles dannelse for alle ved at bygge på de af fornuften fortolkede naturlove, principielt uden brug af religionen. 3) Deismen, der bliver en bærende tankeform, hvor man forstår naturen og samfundet som velordnet skabte størrelser, som det nu helt igennem er op til mennesker at fortolke og forvalte. 4) Humanismen, der sætter sig igennem som en universel verdensfortolkning, hvor mennesket sættes i centrum i stedet for Gud. 5) Mobiliseringen, der kommer til at betyde, at de givne fortolkningsrammer rystes, idet enhver nu selv må afgøre sig for sine tilhørsforhold og sin livsforståelse. 6) Autenticitetsbehovet, der betyder, at alle afgørelser omkring værdier og identitetsmæssig orientering overlades til individets personlige oplevelse og erfaringsdannelse.

Taylors 500 sider lange historiske analyse er det bedste, foreliggende bidrag til forståelsen af sekulariseringens grundlæggende betydning: Religion i form af protestantisk prægede kristendomstyper er på den ene side med til at give plads for seku-

8/Volume 1-2, 2006 og senest Martin 2010. 
lariseringsprocessen, mens religionen på den anden side selv transformeres i processen. Samfundet efterlades således dybt præget af protestantisk kristendom m.h.t. grundlæggende institutions- og mentalitetsformer, men samtidigt principielt frigjort fra religion. I den efterfølgende mere end 300 siders analyse af "Conditions of Belief" sidst i bogen fremlægger Taylor sin beskrivelse af, hvad han opfatter som individets nye betingelser for eksistentiel meningsdannelse og dermed for religion og tro.

Det er afgørende, at religionen er blevet 'ekskarneret' fra det sociale og kropslige dagligliv (Taylor 2007, 554). Hvad der er tilbage af religiøs praksis, fx omkring overgangsritualer, har vi 'vikarer' (fx præster) til at forestå (ibid., 522). Vi har løse forbindelser mellem tro, tilhørsforhold og praksis (believing, belonging og behaving, ibid., 514ff). Religion er ikke mindst i den protestantiske verden gennem de sidste 500 år blevet noget for hovedet, noget, som man selv må tage stilling til, for eller imod. Netop det forhold, at religion mere og mere er kommet til at "reside in the head" (ibid., 613), er problemet, for vores hoveder er sat på en umulig opgave: Vi lever i dag så godt som alle med flere indbyrdes konkurrerende betydningshorisonter: Det er ikke udtryk for vægelsind eller individualisme, men givne livsbetingelser, når mennesker, som vi er flest, pendler mellem fx en humanistisk, en naturalistisk og en religiøs eller spirituel livstydning, som vi bruger i forskellige dele af vores hverdagsliv og selvforståelse. Situationen er præget af en gennemgående polydoksi med åbenlyse dissonanser, der er karakteristisk for danskernes hverdagsreligion - og måske generelt for ikke-eksperters religiøse orientering (Johannessen-Henry \& Rubow 2010). Taylors teori om, at vi i vesten lever i en historisk ny situation med krydspres mellem forskellige betydningshorisonter, er dog den mest grundlæggende tolkning af situationen.

Endnu i min barndom på et husmandssted i Vestjylland i 1950'erne kunne man tale om, at vi levede under én og næsten kun én tronhimmel, nemlig den synlige himmel og de overvejende kirkeligt-kristne betydninger, der knyttede sig til den, sådan som Peter Berger forestillede sig den religiøse urtilstand før sekulariseringen (Berger 1969). Under industrialiseringen blev himlen som religiøs betydningshorisont marginaliseret i forhold til mere rationelle kalkulesystemer. I dag kan man beskrive situationen sådan, at vi alle er omgivet af forskellige betydningshorisonter eller tronhimle, som lader enhver af os leve i et evigt krydspres mellem forskellige forståelsesmuligheder, hvor immanente forståelsesmuligheder veksler med transcendent orienterede (Taylor 2007, 594ff). Individualismen og markedsgørelsen hører med i billedet, når mennesker i dag bruger forklaringselementer fra helt forskellige forståelsessystemer, fx forskellige former for naturvidenskab og endnu flere former for alternativ medicin foruden religion. Det afgørende er imidlertid, at det er et livsvilkår - ikke blot noget man vælger, som man lyster - når mennesker fremstår som om de shoppede på markedet for at skabe deres egen livsholdningsmæssige 'bricolage'. De kæmper med deres liv under de efter sekulariseringsprocessen gældende eksistentielle livsorienteringsvilkår, vil Taylor sige.

Denne generelle beskrivelse af betingelser for eksistentiel meningsdannelse, suppleres hos Taylor af hans berømte teori om 'the subjective turn', som er en betegnelse for, at den moderne individorientering, sådan som den kobles med autenticitetsbeho- 
vet, som er blevet et vilkår for os alle og for alle former for kultur og kommunikation i de vestlige samfund. I The Ethics of Authenticity har Taylor instruktivt beskrevet autenticitetsbehovets opkomst og udbredelse som en demokratisering af romantikkens deistiske ide om det unikke individ:

There is a certain way of being human that is my way. I am called upon to live life in this way, and not in imitation of anyone else's. But this gives a new importance to being true to myself. If I am not I miss the point of my life, I miss what being human is for me.... Being true to myself means being true to my own originality, and that is something that only I can articulate and discover. In articulating it, I am also defining myself. I am realizing a potentiality that is properly my own. This is the background understanding of the modern ideal of authenticity and to the goals of self-fulfilment and self-realization in which it is usually couched. This is the background that gives moral force to the culture of authenticity, including its most degraded, absurd, or trivialized form. It is what gives sense to the idea of "doing your own things" or "finding your own fulfilment" (Taylor 1991, 28f).

Når vi i Norden i flere årtier har hævdet, at vi hver især er 'kristne på min egen måde' (Hamberg 1989), skyldes det hverken akut selviscenesættelse eller knæfald for markedet, hvor enhver jo køber sit - om end fra de samme hylder. Det skyldes, at vi kun kan orientere os ud fra det, som vi tror er særligt for os som enkeltindivider, allerhelst knyttet til en personlig erfaring, som hin enkelte iblandt os har haft. Erfaring må der til, for kun 'min erfaring' kan jeg regne som helt min egen. Det kan godt ske, at enhver ikke bliver salig i sin tro, men man bliver i hvert fald ikke salig i andres tro. Kun den tro kan virke, som er ens egen. I den situation er det langt fra givet, at præstens eller healerens religiøse selvforståelse er identisk med eller blot lader sig omplante til min. Jeg er henvist til at være autentisk og derfor negligere, bruge eller misbruge allehånde religiøse traditioner på mine egne betingelser. Ja, jeg kan faktisk ikke bruge dem til noget som helst, hvis jeg ikke oplever, at de fungerer på just mine betingelser. Om det er præsten eller healeren, som virker mest autentisk for mig, viser sig i praksis. Det afgørende er, om der er plads til, at jeg kan være mig selv (Gundelach et al. 2008, 219224).

Når man ser på disse grundtræk af sekulariseringens konsekvenser for subjektet, er det klart, at sekulariseringens betydning er både omfattende og radikal. I praksis forholder de fleste sig klart anderledes til 'religion' i dag end deres forældre for slet ikke at tale om deres bedsteforældre. Der findes stadigt steds- eller tidslommer, hvor mennesker helt, men oftest kun delvist, lever med nye udgaver af gammel religiøs praksis og tankegang, som var udbredt for længe siden. Men for de fleste har sekulariseringen sat sig igennem med afgørende styrke - især i årtierne med den anden industrialisering efter Anden Verdenskrig, mens den på det registrérbare plan til dels har stået i stampe siden 1980 (Lüchau 2005; Andersen \& Lüchau 2011). Hvor den tyske teolog Dietrich Bonhoeffer under Anden Verdenskrig i sine fængselsbreve måtte fordre, 
at de kristne nu skulle tage fuldt ansvar for deres egen gøren og laden, stillet over for nazismens livsødelæggende ondskab, ved at leve, som om Gud ikke er til (etsi deus non daretur, Bonhoeffer 2006), lever danskerne i dag, uanset at de fleste af dem siger, at de tror på Gud, praktisk talt, som om Gud ikke er til. Religion betragtes som et personligt anliggende uden bestemte praktiske følger, noget, som nogle mennesker har oppe i deres hoveder, og som ikke har større betydning ud over den personlige fornøjelse, medmindre religionen skulle 'gå folk til hovedet' ved at begynde at styre deres handlinger og fællesskaber. Det sker dog kun sjældent, bl.a. just fordi krydspresset fra de forskellige betydningshorisonter ( $\mathrm{fx}$ naturalismen, humanisme og religion) holder mennesker på plads, så de ikke knytter sig for ensidigt til én horisont. Kræftpatienter og mange med dem lader intet uprøvet: den medicinske og kirurgiske behandling respekteres, men den suppleres med alternativ medicin og måske forskellige spirituelle praksisformer - og skulle der være en Gud foroven, der ser i velvilje til den syge, er det også helt fint.

\section{Religionens beskaffenhed i dag}

Som man spørger i skoven, får man svar. Spørger man med den moderne religionsvidenskab, er religion primært 'belief', altså et trosindhold, som religiøse mennesker har i deres hoveder. Dermed er religionsforskerne i smuk overensstemmelse med den indskrænkede udgave af religion, som sekulariseringsprocessen ifølge Taylor har efterladt os med. Riis og Woodhead karakteriserer situationen således:

A belief based approach to religion is now so well established in academic discourses that it is common to find the terms "religion" and "belief" being used synonymously, or to read studies that assume, that an inability on the part of the individuals to articulate their beliefs clearly and systematically implies a dilution or diminution of religion (Riis \& Woodhead 2010, 3). ${ }^{4}$

Karakteristikken rammer hovedtendensen i situationen ganske godt. Ofte ligger vægtningen af belief med en vis nødvendighed allerede i oplægget som fx i de europæiske værdistudier (Andersen \& Lüchau 2011). Men ofte bliver den også valgt med vejende faner som den helt rigtige i frie studier af religion i dag, fx i Zuckerman 2008. I begge eksempler gælder det, at resultaterne - svarene på det, man har spurgt om - generelt er gode nok.

Hvad fx Zuckerman har gjort, har han gjort vel - og med vigtige resultater. Det er således en vigtig information om religion i Danmark i dag, at mennesker, som vi er

4 Linda Woodhead har for sin del gennemført en kritisk diskussion af forskellige modeller for religionsforståelse, mundende ud i et forslag om en konsekvent magtkritisk omgang med religionsdefinitioner (Woodhead 2009). 
flest, ikke skænker meningen med livet mange tanker i det daglige. Ej heller er vi særligt bange for at dø. Som vi er flest, er vi så privilegerede, at meningen med vores liv er vores liv, og meningen med det, vi gør, er det, vi gør. Et eller andet sted ved vi godt, at vi skal dø - vi ved sågar, at det kan ske, før vi venter det; men så er der jo så meget des mere grund til at fokusere på det gode liv, vi lever her og nu. I det daglige giver hverken behovet for mening eller angsten for døden anledning til religiøs refleksion hos danskerne, som vi er flest. Vi kunne måske godt gætte på, at det var sådan; men nu har Zuckerman med sin belief-forskning dokumenteret det ganske grundigt.

Man kunne tænke, at belief-forskerne nu blot bør reflektere deres resultater i forhold til Charles Taylors sekulariseringsteori. Så er forskningen igen på højde med den religiøse situation, for - som Taylor selv peger på det - religionen er jo nu blevet indskrænket til noget, som man kan have i hovedet, hvis man altså har det. Så må man vel just spørge om, hvad folk har i hovedet, hvad de tænker og mener, hvis man vil finde de religiøse rester? Ja, men det slår ikke til blot at lave interviews.

For det første må man nøje overveje, hvilke grupper man arbejder med - og i hvilke situationer? Taler man kun med travle hverdagsdanskere, som man låser fast i en lille tidslomme i en travl hverdag, får man lettest resultater som Zuckermans. Anderledes resultater kan man få, hvis man møder danskere i helt andre sammenhænge. Man får mere åbne resultater, hvis man kan tale med børn i forskellige aldre, jf. fx Larsen \& Sørensen 2005, der konkluderer, at "gudstro med forbehold udgør nærmest fra første færd danskernes måde at forholde sig til den sag på” (Larsen \& Sørensen 2005, 161). Taler man med danskere i forbindelse med deres hyppige og ganske regelmæssige deltagelse i kirkelige handlinger, specielt barnedåb og begravelse, får man andre overvejelser (Rykind-Eriksen 1993). Taler man endelig med danskere med akutte, kroniske eller terminale, sygdomme, som det gennem de senere år er sket i snart en snes forskellige projekter med tilknytning til forskningsnetværket 'Tro og helbred', får man, som jeg skal vende tilbage til det, helt andre resultater.

For det andet er det afgørende, hvordan vi taler med mennesker. I Ina Rosens ph.d.afhandling såvel som i flere gruppeinterviews i forbindelse med forskningsnetværket 'Tro og helbred' viser det sig, at mennesker har - eller langsomt får - en del mere at sige, når de er flere om det og så at sige kan låne ord og stemninger fra hinanden (Rosen 2009). Det er en misforståelse, hvis vi tror, at religion er en individuel privatsag, som kun kan og skal graves ud af den enkeltes hoved. Religion er i høj grad en social og kommunikativ sag, som traditionelt udfoldes i fælles ritualer, sang og bøn. Selv om de gamle former er svækkede, bortset fra overgangsritualerne, har vi brug for at låne ord af hinanden, til nød af en interviewer, men bedst fra mennesker, der ligner os selv, før vi kan sætte egne ord på vore egne holdninger. Måske er mekanismen omtrent, som når man skal skrive i gæstebøger: Man kigger hurtigt efter, hvad de andre skrev, og så finder man sit eget udtryk derudfra. Sådan foregår det også, når patienter og pårørende skriver i gæstebogen i kirkerummet på Rigshospitalet i København (Nygaard 2010). 
For det tredje kan det meget vel være, at vi er på vej mod en situation, hvor der mange steder vitterligt er meget lidt religiøs betydningshorisont at forstå ens liv ud fra. Den ældre generation af store religionssociologer har lært os, at religion for flere og flere er noget, vi har glemt og har vikarer (præster) til at tage sig af for os (jf. fx Davie 2000). I dag er der imidlertid flere og flere mennesker, der ikke har lært så meget, at de har noget at glemme. Helt uafhængigt af de nye ateisters indsats er vi på vej mod en ny radikal form for sekularitet i et voksende mindretal, som mere og mere kommer til at ligne flertallet i det gamle Østtyskland, hvor kun ca. 20 procent er kirkemedlemmer med et kendskab til kristendommen svarende til flertallet blandt lidt ældre danskere, som fortsat har nogle salmestumper at nynne på og foreslå til begravelserne i den nære familie (Iversen 2010, 1f.; Herbst 2010, 6; Martin 2010, 149-164). Ikke engang Dalai Lama interesserer østtyskerne sig for (Herbst 2010, 9). Den østtyske lutherdom gav tidligt rum for individualisme og i 1800-tallet for udbredt fritænkeri. Samtidigt betød kirkens afhængighed af statsmagten, at den stod svagt, da først nazisterne og siden kommunisterne overtog staten. Østtyskland er således ligesom Danmark et eksempel på den statssponsorerede sekularisering, som ligger latent i protestantismen, særligt lutherdommen. De er dog den forskel, at staten i Danmark (hidtil) har fundet det opportunt at opretholde kirkeinstitutionen intakt, mens den kommunistiske stat bevidst søgte at tømme den for medlemmer og betydning (Martin 2010, 152).

For det fjerde er det en afgørende indsigt, at ord stammer fra kroppen - og at kroppen behøver ord. Mennesker er kroppe med en eksistentiel dimension (von der Fehr 2008), kroppe, der tænker (Merleau-Ponty 1994). Der er gode grunde til at definere tro som "en kropsbaseret følelse af vished" (von der Fehr 2008, 87), der er mere grundlæggende end det kognitive niveau. Tro grunder i en kropsbaseret vished om, at livet vil sejre i kroppens livskamp. Alt om religion er således ikke sagt med den kognitivt orienterede religionsteori, der i praksis impliceres i de gængse sekulariseringsteorier.

Endelig for det femte er den gode religionsforsknings anliggende ikke uden videre udtømt den dag, religionen måtte være forsvundet. Den eksistentielle orienteringskamp, som hidtil oftest har udspillet sig i religiøs klædedragt, bliver ikke mindre vigtig, hvis det religiøse sprog og de religiøse praksisser en dag ikke længere måtte være til rådighed. Den eksistentielle grundorientering, som religionen traditionelt har leveret de grundlæggende sproglige ressourcer til, suspenderes ikke, blot fordi religionen evt. kommer til at stå svagere som ressource. Den kan lige så vel udmøntes fx spirituelt eller sekulært som religiøst (la Cour \& Hvidt 2010).

Jeg vil uddybe disse punkter, idet jeg vil opstille og diskutere et skema over religionens dimensioner, sådan som de tager sig ud under sekulariseringen. Dernæst vil jeg belyse punkterne ved at gengive og analysere et uddrag fra et af de mange interviews fra tro og helbred-forskningen. 
Religionens dimensioner i dag

\begin{tabular}{|l|l|l|}
\hline $\begin{array}{c}\text { Kulturens dimensioner } \\
\text { ifølge J.A. Fishman (1980) }\end{array}$ & $\begin{array}{l}\text { Empiriske dimensioner af re- } \\
\text { ligion i Denmark } \text { i dag }\end{array}$ & $\begin{array}{l}\text { Ninian Smart's Dimensions } \\
\text { of the Sacred (1947) }\end{array}$ \\
\hline $\begin{array}{l}\text { Knowing } \\
\text { Det kognitive } \\
\text { Believing }\end{array}$ & $\begin{array}{l}\text { Bekendelser og lære } \\
\text { Symboler }\end{array}$ & $\begin{array}{l}\text { Doctrine and Philosophy } \\
\text { Myths and Narratives }\end{array}$ \\
\hline $\begin{array}{l}\text { Doing } \\
\text { Praksis } \\
\text { Behaving }\end{array}$ & $\begin{array}{l}\text { Ritualer } \\
\text { Ethos, mentalitet og institutioner }\end{array}$ & $\begin{array}{l}\text { Rituals } \\
\text { Ethos and Legislation } \\
\text { Social, material and political Di- } \\
\text { mensions }\end{array}$ \\
\hline $\begin{array}{l}\text { Being } \\
\text { Identitet } \\
\text { Belonging }\end{array}$ & $\begin{array}{l}\text { Social og kommunikativ væren } \\
\text { Følelser } \\
\text { Søgen efter eksistentiel mening -i } \\
\text { kroppe, der tænker }\end{array}$ & $\begin{array}{l}\text { Religious Experiences } \\
\text { Religious Emotions }\end{array}$ \\
\hline
\end{tabular}

Jeg tager udgangspunkt $\mathrm{i}$ to former for dimensionsopdelinger: Til venstre har vi sociolingvisten J.A. Fishmanns dimensionering med knowing, doing og being, som oprindeligt er fremlagt i en teoretisk diskussion af begrebet etnicitet, men også har vist sig brugbar i mentalitets- og religionsstudier (Fishman 1980, jf. anvendelsen i Gundelach et al. 2008). Den korrelerer med en gængs religionssociologisk skelnen mellem believing, behaving og belonging, som igen matcher dimensionerne: det kognitive, praksis og identitet. Til højre har vi religionsfænomenologen Ninian Smarts dimensionering af religion, sådan som den senest er fremlagt i Smart 1997 [1996].

Endnu for ti år siden var der stor tilslutning til Clifford Geertz' kulturteoretiske begreb om religion som et symbolsystem (Iversen 2004). Senere skiftede vægtningen mange steder i retning mod at se på den rituelle praksis som religionerne kerneområde - bl.a. under indtryk af omfattende religionshistorisk forskning (se fx Riesebrodt 2007). Senere igen er det fremhævet, at religion og religiøsitet er dybt forviklet med samfundets ethos og mentalitet, der igen interagerer med den basale institutionelle praksis i samfundet (Gundelach m.f. 2008). På det seneste forekommer det som nævnt slående, at forskellige former for kollektive interviews og fokusgrupper ser ud til at kunne artikulere ganske meget mere materiale om religion, end man ofte ser i individuelle interviews som fx Zuckermans (Rosen 2009). Allersenest har Ole Riis og Linda Woodhead (2010) søgt at rehabilitere følelsesdimensionen i studiet af religion, idet de kraftigt understreger, at religiøse følelser er dybt indfældede i kollektiv og symbolsk praksis. 


\section{Empiriske dimensioner af religion i Denmark i dag}

Når jeg ser på den observérbare religion i Danmark i dag, sådan som den fremtræder i empirisk baserede fremstillinger (Andersen \& Lüchau 2011) og ikke mindst i interviewene fra tro og helbred-projekterne, viser der sig følgende billede. Bekendelser og lære står umiddelbart svagt, mens der er en betydelig interesse for symboler. Man kan her tænke på den markante måde, hvorpå centrale tekster som Fadervor og Den Apostolske Trosbekendelse gennem de senere år har vundet indpas som fælles fremførte tekster (ved sang eller fremsagt i kor) i folkekirkens ritualer, også blandt såkaldt kirkefremmede ved dåb og begravelse. Formelt set er der tale om bekendelse og lære; men i praksis handler det om, at mennesker går med en tur ind i et symbolunivers, som - for en tid - får lov at supplere deres normale repertoire af betydningsuniverser. En parallel tendens ses, når der i dag er flere, der går i kirke sporadisk, skønt der er færre, der gør det regelmæssigt (Andersen \& Lüchau 2011, 80). Det er øjensynligt det samme, der sker, når Grundtvigs "Hil dig frelser og forsoner" og Ingrid SchrøderHansens "Tak, Gud, for denne lyse morgen", sunget for fuld udblæsning, hitter blandt de 70 procent af landets unge, der følger folkekirkens konfirmandundervisning. Der er næppe tale om bekendelseshandlinger, men - ganske entusiastiske - eksperimenter med et kristent symbolunivers som betydningshorisont.

Det store, empiriske materiale fra netværket Tro og helbred i form af enkeltinterviews og fokusgruppeinterviews især med kræftpatienter og KOL-patienter 5 i sygdommens sene stadier anser jeg for at være særdeles vægtigt. Jeg skal her nøjes med at fremlægge og diskutere et enkelt længere citat fra en kvindelig KOL-patient, som jeg har fået stillet til rådighed af ph.d.-studerende, sygeplejelærer Ingeborg Ilkjær:

Jeg har ingen tro, nej. Nej, ikke i øjeblikket. Jeg har ellers været troende. Da jeg var barn gik jeg i søndagsskole hver søndag, indtil jeg begyndte til præst, og jeg havde en rigtig, rigtig god præst. Han havde sådan nogle diskussionsklubber hjemme i sin stue, og det var der, vi diskuterede om en mening med livet, og så bralrer jeg op om at krig, og sygdom og det meningsløse, hvis der var en Gud, var der ikke krige og sygdom, jeg kunne pludselig ikke se, at der skulle være nogen Gud, overhovedet. Så forlod troen mig. Den har jeg så ikke fundet siden. Det har jeg ikke. Jeg ved også, at når vi er døde, så er vi døde. Det er det, og så er der ikke mere der. Men alligevel så tror jeg på, at måske sjælen, selv om det er noget pladder. Altså jeg tror på, at der er noget mellem himmel og jord. Det tror jeg. (I: Når du har det rigtig dårligt, er det så en verden du bruger?) Nej det er det ikke, men man har det jo nok inden i ikke, fordi jeg har holdt meget på, at mine børn skulle døbes, og at mit barnebarn blev døbt, og så den ene af pigerne ikke blev døbt, det blev jeg gal over...

5 Patienter med kronisk obstruktiv lungelidelse, ofte kaldet rygerlunger, skønt rygning ikke er den eneste årsag til denne kroniske og i sidste instans dødelige lidelse. 
Når jeg havde det rigtig dårligt, så for at falde i søvn, så er jeg nødt til at tænke på min mormor ... mens jeg var barn. Når hun kom og puttede mig ned i den her lille seng jeg lå i ... tænk så falder jeg i søvn, og hvis der er noget jeg er ked af, så sidder jeg altid og tænker, mormor kan du ikke hjælpe mig. Hun var der bare hele tiden, og stille og rolig, og hun havde løsning på alle problemer, det var lige meget, hvad man kom med så ..., det kunne mormor, hun blev aldrig sådan rigtig gal. (I: Så det du gør Bodil, er det at du henter hende frem fra din erindring til hjælp nu?) Ja, det er det, ja, jeg ser hende sidde der og flette sin knold. Hun holdt af mig, det er det største tab i hele mit liv, det var hende. Det gjorde meget ondt, at miste hende. (I: Du har jo ikke mistet hende helt?) Hvis jeg ikke kan falde i søvn, hvis jeg er lidt ked af det, så kan jeg godt, bare mormor var her, så lukker jeg øjnene og når hun havde bagt franskbrød og lavede te til mig, det var ikke fordi hun gik og krammede mig, men hun var der bare hele tiden. Hun gav mig tryghed for den havde jeg jo ikke, min mor blev enke tidligt ikke, og jeg var barnepige tidligt og skulle tage mig af de små søskende. (I: Du bruger altså erindringerne og de gode minder?) Ja da, jeg kan godt sige: Mormor, kan du høre mig og kigge op i skyerne. (I: Så tror du hun er et eller andet sted?) Ja, på den måde har jeg en tro, men jeg har ikke en tro på, at der er en Gud. Så mormor er nok min Gud.

Interviewpersonen, der har navnet Bodil i undersøgelsen, er først i tresserne, og har arbejdet som kassedame m.m. indtil for to år siden. Nu er hendes hverdag optaget af kampen mod den stadigt tiltagende åndenød. Jeg har valgt disse uddrag af det i alt snart 20 sider lange interview om Bodils eksistentielle situation under sygdommen, fordi jeg finder, at det samlet set giver det mest eksemplariske udtryk for, hvad man kan møde i de mange interviews fra tro og helbred-forskningen. Repræsentativt kan intet enkelt interview være, allerede fordi de alle reflekterer hver deres unikke situationer med den enkelte interviewpersons særlig udtryk for livstydning og eksistentielle udfordringer.

Bodils situation og sprog er anderledes, end situationen og sproget hos Zuckerman interviewpersoner. Og så dog: Det er Bodils grundholdning, at hun ikke tror på Gud og ikke har gjort det siden teodicé-diskussionerne under konfirmationsforberedelsen. Men samtidigt taler hun om 'Gud' som agenten bag hendes skæbne. På den måde er der i det mindste én, hun kan holde ansvarlig. Man kan her tale et krydspres mellem en immanent og en transcendent betydningshorisont. Man kan også se Bodils tale om 'Gud' på linie med den konfirmandernes højstemte “Tak, Gud, for mine gode venner, tak, Gud, at nogen elsker mig" i Schrøder-Hansens sang: Når noget er vigtigt, må vi sætte trumf på, og Gud er fortsat trumf, uanset om det er Bjarne Riis, der har vundet, eller det er dronningen, der siger "Gud bevare Danmark", som folkeligt set betyder, at vi skal være gode ved hinanden og passe godt på vores land (Gundelach m.fl. 2008, 150). Man kan bruge ordet 'Gud' som et sproglån, hvor sproget ellers ikke slår til. Men måske er der alligevel mere på spil hos Bodil. Hun ville gerne have en 'Gud' til at passe på sig, sådan som mormor gjorde det engang. Og når hun nu engang for længe siden har gjort den dybt personlige erfaring, at verdens uretfærdighed ikke lader sig forene 
med troen på 'Gud', så må mormor være hendes Gud. Bodil har som mor og fagforeningsaktiv taget meget ansvar i sit liv, men hun har aldrig været så grusom at straffe det gode med det onde, sådan som hun oplever, at livet nu gør det med hende. Det er uretfærdigt!

Det er et begrænset religiøst sprogrepertoire, Bodil har med sig i kroppen. Det er uklart, om den bønspraksis, som hun har haft ved børnenes sengekant, aktualiseres hos hende, som det ofte sker under akut sygdom (Ausker et al. 2008). Bodils eksistentielle orienteringskamp er imidlertid meget intensiv. Hun er en krop, der tænker! Jo mere hun mærker sit krop som sit livs vilkår og skæbne, jo mere reflekterer hun over sit liv og den forestående død. Med en vis ret kan man mene, at hun søger den hvile eller det eksistentielle balancepunkt, som Taylor med et måske lidt for stort ord kalder 'fullness'. Et menneske er imidlertid en historisk bestemt krop, der tænker. Mennesket er bestemt af livshistorien, så det har noget og ikke noget andet med sig i kroppen. Bodil har oplevelsen af trygheden hos mormor med sig som afgørende hvilepunkt.

Når danskernes eksistentielle livskamp intensiveres under akut sygdom, betyder det ikke, at sekulære mennesker bliver religiøse eller for den sags skyld spirituelle. Menneskers orienteringssøgning finder primært sted inden for de ressourcer, vi har med os i kroppen, de være sig sekulære, religiøse eller spirituelle (jf. la Cour \& Hvidt 2010). Således er det også for Bodil: Hun har noget med fra en religiøst troende barndom, men har også er evne til at lukke af og klare sig selv, opøvet gennem et langt, ofte krævende voksenliv. Hun er i disse henseender en central repræsentant for den generation, der har sunget morgensang i skolen og ofte lidt mere til, men som siden har haft travlt med at tage vare på sig og sine. Gennem livet har hun ikke haft brug for at regreere til barndommens gudstro, skønt hun yderst standhaftigt og håndfast har holdt fast på barnedåben og helst også konfirmationen, selv om hun er sig meget bevidst, at hun egentlig ikke kan begrunde noget af det. I det ensomme liv med åndenød regreerer Bodil nu delvist til barndommens gudstro, men som hovedsag fastholder hun, at Gud ikke er til, i hvert fald må hun leve uden Gud, hvis hun vil holde sig til den erfaring og fornuft, som er ægte for hende. "Jeg ved ..., at når vi er døde, så er vi døde." Alligevel lader hun en dør stå åben, hun "tror på, at der er noget mellem himmel og jord."

At dømme ud fra Bodils eksempel, der som sagt langt fra står alene, er det den kropsligt bundne eksistentielle søgen efter mening i det liv, hvor hverdagens rytme og iboende mening ikke længere holder os oppe, der sætter gang i de religiøse spørgsmål.

\section{Danskernes agnostiske deisme}

Teismens og metafysikkens Gud er akkurat så død eller uaktuel blandt danskere flest, som Nietzsche kunne ønske sig det. Selv om danskernes store flertal selv mener, at de er 'troende', er det ikke primært 'Gud' de tror på. 'Gud' er primært til stede som en sproglig ressource, når der skal udtrykkes store følelser og dybe eksistentielle anlig- 
gender. Det samme gælder bestemte religiøse praksisformer, særligt ved overgangsritualer og bøn i særlige situationer. Selv om de mindretal, der tilsluttede sig de gudelige vækkelser, troede på en levende, indgribende Gud, er der næppe tvivl om, at deismen har været den dominerende form for gudstro i Danmark i 200 år (Iversen 2010). Dansk flertalsreligion er og har i 200 år været variationer over rationalismens og folkereligionens tro på Gud, dyd og udødelighed (Iversen 2005). For så vidt har danskerne i 200 år levet med Grundtvigs og vækkelsernes store spørgsmål: Hvor hører vi Guds ord til os i en situation, hvor Gud ligner en pensioneret urmager? Svar har danskerne flest aldrig rigtigt fundet.

Deismen er hos Taylor overbevisende beskrevet som sekulariseringsprocessens afgørende vendepunkt, der betyder, at vi i dag er evigt opsatte på at finde en 'plan', selvom vi ikke længere tror på, at der er eller nogensinde har været en planlægger (Taylor 2007, 221f. og 543). 1800-tallet i europæisk og dansk kultur var domineret af en stærk gudstro - af deistisk karakter. Senest har Thorkild Kjærgaard mindet os om, hvor stærk religiøst begrundet og forstået deismen var (Kjærgaard 2010). Gud var endnu ikke sekulariseret, men tendentielt pensioneret. Troen på skabelsen og skaberens visdom var så stærk som nogensinde. Ud fra ens egen kloge blik på naturen, kosmos, historien og menneskelivet kunne man stadigt sige med Paulus: "O dyb af Guds rigdom og visdom og kundskab" (Rom 11,33). Senere blev deismens mindre religiøs og mere rationel fx i kølvandet på udviklingslærens fremskridt. I dag er vi der, hvor "the Plan is without a Planner" (Taylor 2007, 543).

Det er irrationelt at tro på Gud, for man kan jo ikke vide noget om Gud. Det kan jo sagtens være, at alt det om Gud slet ikke passer! Danskerne, som de er flest, svarer noget i retning af: "Ikke så meget", sådan som en ung kvinde gjorde det i TVs Kirkeligt Magasin, da hun blev spurgt, om hun troede på Gud. Forfatteren Anders Bodelsen bemærkede ganske præcist i sin TV-anmeldelse (i Politiken 23. januar 1975) hertil, at det svar er udtryk for den gode danske tankegang, at "man skal vise Gud den respekt, der bunder i, at man trods alt ikke kan være helt sikker på, at han ikke eksisterer". ${ }^{6}$ Danskere lever i praksis, som om Gud ikke er til, selv om de tror 'lidt' på ham. 'Guds plan' med det hele og specielt vores eget liv vil vi helst kunne tro på. Danskerne er en slags deister; men samtidig er de på vej til at blive agnostikere, for man kan jo aldrig vide! Danskernes hovedreligion er agnostisk deisme, der i krisesituationer kommer til udtryk som eksistentiel polydoksi. Det er antageligt forklaringen på de tilsyneladende selvmodsigende svar, der findes i de nyere tal fra de historiske interviewundersøgelser, som Peter Lüchau har gravet frem: I en undersøgelse fra 1979/80 siger $45 \%$ af de adspurgte ja til, at Gud findes, mens 59 \% af samme gruppe siger, at de tror på Gud (Lüchau 2004, 9)!

Danskere er glade for at være troende, men ikke for at være religiøse. Danskerne vil ikke lukke af over for den sproglige og eksistentielt orienteringsmæssige mulighed,

6 Sjældnere er det at høre det sagt, som Tøger Seidenfaden skriver i et posthumt kapitel til en ufærdig bog: “Grundlæggende tror jeg ikke, fordi jeg ikke mener, at der er noget tro på" (Politiken 30. januar 2011). 
som det er at tale om Gud. Det er givetvis kun et lille mindretal, der tror på Gud i fuld metafysisk, teistisk udgave. Når Niels Grønkjær (2010) taler om ‘Den nye Gud' som en ikke-teistisk Gud, er han, trods forfærdelse på kirkens ortodokse fløj, kun langsomt ved at udvikle en kristen teologi, hvor der kan tales om Gud på en måde, som er kompatibel med religionens beskaffenhed i Danmark i dag (Grønkjær 2010). ${ }^{7}$

\section{LITTERATUR}

After Secularization

2006 The Hedgehog Review Volume 1-2.

Andersen, Peter \& Peter Lüchau

2011 "Individualisering og aftraditionalisering af danskernes religiøse værdier", in: Peter Gundelach, ed., Små og store forandringer. Danskernes vxrdier siden 1981, Hans Reitzels Forlag, København, 76-96.

Ausker, Nadja et al.

2008 "Danske hospitalspatienter intensiverer eksistentielle tanker og religiøst liv", Ugeskrift for Læger 170 (21), 1828-1838.

Berger, Peter

1969 The sacred canopy. Elements of a sociological theory of religion, Doubleday, New York.

Bonhoeffer, Dietrich

2006 Min tid er dine hænder. Vennebreve og teologiske refleksioner, Aros, Frederiksberg.

Bäckström, Anders et al.

2004 Religious Change in Northern Europe. The Case of Sweden, Verbum, Stockholm.

Davie, Grace

2000 Religion in modern Europe, a memory mutates, Oxford University Press, Oxford.

Fehr, Drude von der

2008 Når kroppen tenker, Universitetsforlaget, Oslo.

Fishman, J.A.

1980 "Social Theory and Ethnography: Language and ethnicity in Easter Europe", in: P. Sugar, ed., Ethnic diversity and conflict in Eastern Europe, ABC:Clio, Santa Barbara/Oxford, 69-99.

Geertz, Clifford

1973 The Interpretation of Cultures. Selected Essays, Basic Books, New York.

Grønkjær, Niels

2010 Den nye Gud, Anis, København.

Gundelach, Peter, Hans Raun Iversen \& Margit Warburg

2008 I hjertet af Danmark. Mentaliteter og institutioner, Hans Reitzels Forlag, København.

Habermas, Jürgen

1982 Theorie des kommunikativen Handelns, Bd. 1-2, Suhrkamp Verlag, Franfurt am Main.

2006 Times of Transition, Polity Press, Cambridge.

2008 Notes on a post-secular society, http:/ / www.signandsight.com/features/1714.html (set 13. januar 2010).

7 Grønkjær kan meget vel have ret i, at troen som eksistentielt engagement (faith), der står stærkt blandt danskerne, kolliderer med troen som religiøst indhold (belief), som stadig har en traditionel teistisk gudstro som implicit orienteringspunkt (mail af 11. august 2011). 
Hamberg, Eva

1989 Kristen på mit eget sätt - en analys av material från projektet Livsådskådningar i Sverige, Religionssociologiska Instituttet, Stockholm.

Herbst, Michael

2010 Secularization as a Challenge for the Missional Church, http:/ / www.fkm.dk/upload/filer/artikler/ michael-herbst-secularization-and-missional-church.pdf (set 22. januar 2011).

Iversen, Hans Raun

2004 Religionsbegrebet til debat i satsningsområdet 18. februar 2004, http:/ /www.ku.dk/satsning/religion/ indhold/publikationer/anden_litteratur/religionsbegrebet.pdf (set 13. januar 2011).

2005 "Gudstro i den danske religionspark", in: Morten Thomsen Højsgaard \& Hans Raun Iversen, eds., Gudstro i Danmark, Anis, København, 103-124.

2010 "Sekulariseringen som vilkår for kirkens arbejde", Dansk teologisk Tidsskrift 73, 1-24

Kjærgaard, Thorkild

2010 "Tro", in: Ulrik Langen, ed., 1700-tallet - Parykker, profit og pøbel, Politikens Forlag, København.

La Cour, Peter \& Niels C. Hvidt

2010 "Research on meaning making and health in secular society: Secular, spiritual and religious existential orientations", Social Science and Medicine XXX, 1-8.

Larsen, Irene \& Peter Green Sørensen

2005 "Gudsforestillinger i folkeskolen", in: Morten Thomsen Højsgaard \& Hans Raun Iversen, eds., Gudstro i Danmark, Anis, København, 143-162.

Lüchau, Peter

2004 Danskernes gudstro i 50 år. http://www.gudstro.dk, (set 2. januar 2011)

2005 "Danskernes Gudstro siden 1940'erne", in: Morten Thomsen Højsgaard \& Hans Raun Iversen, eds. Gudstro i Danmark, Anis, København, 31-58.

Martin, David

2010 The Future of Christianity. Reflections on Violence and Democracy, Religion and Secularization, Ashgate, Surrey.

Merleu-Ponty, Maurice

1994 Kroppens fxnomenologi, Det lille forlag, Frederiksberg.

Nygaard, Else Marie

2010 Tro og sekularisering: Troens udtryk i en sekulariseret tid, Masterafhandling, Det Teologiske Fakultet, Københavns Universitet.

Riesebrodt, Martin

2007 Cultus und Heilsversprechen. Eine Theorie der Religionen, Verlag C.H. Beck. München.

Riis, Ole \& Linda Woodhead

2010 A Sociology of Religious Emotion, Oxford University Press, Oxford.

Rosen, Ina

2009 I'm a believer - but I'll be damned if I'm religious. Beliefs and Religion in the Greater Copenhagen Area. A focus group study; Lund Studies in Sociology of Religion, Volume 8, University of Lund.

Rubow, C. \& C. T. Johannessen-Henry

2010 "Variationer af liv i døden: Transcendenser i hverdagslivets (nye) polydoksi". Tidsskrift for Forskning i Sygdom og Samfund, 12, 135-55.

Rykind-Eriksen, Kirsten

1993 "'Gud er god.' Begravelsespraksis - set fra de efterladtes side”, in: Birthe Lund \& Hans Raun Iversen, eds., Livshjælp. Undersøgelser af begravelsespraksis og kirkegårdskultur i Danmark Landsforeningen af Menighedsrådsmedlemmer, Århus, 19-94.

Smart, Ninian

1997 Dimensions of the Sacred. An Anatomy of the World's Beliefs [1996], Fontana Press, London. 
Taylor, Charles

1991 The Ethics of Authenticity, Harvard University Press, Cambridge.

2007 A Secular Age, The Belknap Press of Harvard University, London.

2010 "The Meaning of Secularism"', The Hedgehog Review, Fall 2010, Vol. 12, 23-34.

Woodhead, Linda

2009 "Magt og religion i religionsvidenskaben", Religionsvidenskabeligt Tidsskrift 53, 5-23.

Zuckerman, Phil

2008 Samfund uden Gud. En amerikaner ser på religion i Danmark, Forlaget Univers, Århus.

Hans Raun Iversen, lektor, cand. theol. Det Teologiske Fakultet, Københavns Universitet 